CASSOWARY volume 2 (1): 68 - 85

ISSN : 2614-8900

E-ISSN : 2622-6545

CProgram Pascasarjana Universitas Papua, https://pasca.unipa.ac.id/

\title{
Pengelolaan sampah botol plastik air mineral di Kota Sorong guna menurunkan tingkat pencemaran lingkungan
}

\author{
Management of mineral water plastic bottles in Sorong City to reduce the level of \\ environmental pollution
}

Julian Kelly Kambu*, Eko Agus Martanto, Marlyn Lekitoo

Program Studi Ilmu Lingkungan, Program Pascasarjana, Universitas Papua

Jalan Gunung Salju Amban Manokwari 98314

*E-mail : juliankellykambu@gmail.com

\begin{abstract}
Sorong is one of the most advanced and most populous cities in the province of West Papua, with a population of 2016 reaching 232,833 people and a population growth rate of 3.21 percent per year (BPS, 2016). As the most populous city, of course, the problem of waste becomes a significant threat, especially related to the increasing volume of waste production both from households and businesses and also the tendency to dispose of waste improperly that results in environmental pollution. The purpose of this study was to determine the extent of environmental pollution due to plastic waste in the City of Sorong, then look further at the management of mineral water plastic bottles, and determine what factors influence the amount of plastic bottle waste in the City of Sorong. The analytical method used in this research is descriptive qualitative analysis. Based on the results of the study it can be seen that the waste management process is carried out by several parties, among others: carried out by the Government using an integrated management system, then by the community with an individual management system, and by the private sector through the Sorong Raya Garbage Bank. Factors that influence the amount of plastic bottle waste include: The level of community / business actors' knowledge about waste, their attitude about waste management, their behavior in managing waste, and the activities of government administrators such as studies on waste, socialization of facilities and regulations, and the adequacy of the APBD budget. and also external participation.
\end{abstract}

Keywords : Sorong, Garbage, waste management, pollution, plastic waste, waste banks.

ABSTRAK: Kota Sorong merupakan salah satu Kota termaju dan terpadat penduduknya di wilayah Provinsi Papua Barat, dengan jumlah penduduk pada tahun 2016 mencapai 232.833 jiwa dan laju pertumbuhan penduduk 3,21 persen pertahun (BPS, 2016). Sebagai kota terpadat tentu saja masalah sampah menjadi ancaman yang cukup berarti, apalagi terkait dengan meningkatnya volume produksi sampah baik dari rumah tangga maupun pelaku usaha dan juga kecenderungan membuang sampah tidak pada tempatnya yang mengakibatkan pencemaran lingkungan. Tujuan dari penelitian ini adalah untuk mengetahui sejauh mana tingkat pencemaran lingkungan akibat sampah plastik di Kota Sorong, kemudian melihat lebih jauh pengelolaan sampah botol plastik air mineral, dan mengetahui faktor-faktor apa saja yang berpengaruh terhadap 
banyaknya sampah botol plastik di Kota Sorong. Metode analisa yang digunakan dalam penelitian ini adalah analisa deskriptif kualitatif. Berdasarkan hasil penelitian dapat diketahui bahwa proses pengelolaan sampah dilaksanakan oleh beberapa pihak, antara lain: dilakukan oleh Pemerintah dengan menggunakan sistem pengelolaan terpadu, kemudian oleh masyarakat dengan sistem pengelolaan individu, dan oleh swasta melalui kegiatan Bank Sampah Sorong Raya. Faktor-faktor yang berpengaruh terhadap banyaknya sampah botol plastik antara lain: Tingkat pengetahuan masyarakat/pelaku usaha tentang sampah, sikapnya tentang pengelolaan sampah, perilakunya dalam mengelola sampah, dan aktivitas administrator pemerintahan seperti kajian tentang sampah, sosialisasi fasilitas dan peraturan, serta kecukupan anggaran APBD dan juga partisipasi eksternal.

Kata Kunci : Sorong, Sampah, pengelolaan sampah, sampah plastik, bank sampah.

\section{PENDAHULUAN}

Jumlah penduduk Kota Sorong dengan tingkat pertumbuhan yang relatif tinggi membawa akibat bertambahnya volume sampah. Pertambahan jumlah volume sampah adalah berbanding lurus dengan pertambahan jumlah penduduk. Selain pertambahan volume sampah akibat pertambahan jumlah penduduk, fakta empiris juga menunjukkan bahwa jenis sampah yang dihasilkan dari kehidupan sehari-hari masyarakat semakin beragam seiring dengan kehidupan masyarakat yang semakin konsumtif; volume sampah anorganik semakin bertambah seiring dengan pola konsumtif kehidupan masyarakat yang terus berkembang. (Perda Nomor 15 Tahun 2013).

Sampah Kota Sorong merupakan campuran sampah organik dan an organik. Berdasarkan jenisnya sampah Kota Sorong dibedakan menjadi sampah plastik, kertas/karton, kaca/botol, besi/ kaleng, B3 dan organik. Hasil survey dan pengukuran langsung di lapang menunjukkan bahwa sampah Kota Sorong juga didominasi oleh organik $(51,37 \%)$ dan plastik $(17,12 \%)$ dengan massa jenis masing-masing 286,0242 $\mathrm{kg} / \mathrm{m} 3$ dan 123,9438 kg/m3. Massa Jenis total sampah Kota Sorong
$556,7937 \mathrm{~kg} / \mathrm{m} 3$. (Laporan Rencana Induk Penyelenggaraan Prasarana dan Sarana Persampahan Kota SorongTahun 2014).

Sampah botol plastik air mineral tidak dapat terurai secara alami. Tindakan yang dapat dilakukan dalam mengelola sampah plastik botol air mineral yakni dengan mulai mengumpulkan, memilih jenis, memipihkan, mencacah, sampai pada peleburan. Salah satu solusi yang dapat diterapkan dalam penanganan sampah pastik ini adalah dengan mendaur ulang. Bahan plastik merupakan bahan organik yang tidak bisa terurai oleh bakteri (Murtadho Djuli dan Sa'is Gumbira. E, 1988).

Botol plastik jenis PET (Poly Ethylene Terephthalate) merupakan limbah plastik yang tidak dapat diurai oleh tanah sehingga keberadaannya sangat mengganggu lingkungan sekitarnya. Pemanfaatan limbah botol plastik yang dapat merubah bentuknya sangat diharapkan oleh masyarakat, sehingga keberadaannya tidak mengganggu lingkungan lagi. Polyethylene Terephthalate (plastik PET atau PETE) adalah polimer jernih dan kuat dengan sifat-sifat penahan gas dan kelembaban. Kemampuan plastik PET untuk menampung karbon dioksida (karbo- 
nasi) membuatnya sangat ideal untuk digunakan sebagai botol-botol minuman ringan (bersoda / terkarbonasi).

Tujuan penelitian ini adalah untuk mengetahuipengelolaan sampah botol plastik air mineral, faktor-faktor yang berpengaruh terhadap banyaknya sampah botol plastik di Kota Sorong.

\section{METODE PENELITIAN}

Waktu penelitian dilaksanakan di wilayah administrasi Kota Sorong selama 8 (delapan) bulan mulai dari bulan Oktober 2016 sampai dengan bulan Mei 2017. Metode yang digunakan dalam penelitian ini adalah deskriptif kualitatif dengan teknik survei.

Desain Sampling dalam penelitian ini, responden yang menjadi sampel dibagi menjadi beberapa kategori, yaitu: 1. Administrator Pemerintahan, dalam hal ini kepala dinas kebersihan dan Kepala Kelurahan (lurah); 2. Rumah Tangga; 3. Pengusaha warung makan, restoran, hotel dan rumah sakit.

Untuk kategori 1, dilakukan sensus terhadap seluruh populasi untuk mengetahui berbagai karakteristik/ gambaran tentang besaran sampah botol plastik dan pengelolaannya di wilayah administrasi masing-masing. Sedangkan pada kategori ke 2, akan dilakukan pengambilan sampel secara acak dan berkelompok dengan cara multistage sampling.

Banyaknya sampel yang diambil dalam penelitian ini ditentukan dengan menggunakan Rumus Slovin (Walpole, 1995), dimana hasilnya adalah: Administrator Pemerintahan sebanyak 41, Rumah Tangga 100 responden, dan Usaha100 responden sehingga total jumlah responden yang menjadi obyek penelitian ada 241. Penelitian ini menggunakan data yang bersifat primer yang didapatkan dengan metode pengamatan langsung dan wawancara.

Untuk mengetahui faktor-faktor yang berpengaruh terhadap banyaknya sampah plastik yang disetor ke tempat pengelolaan sampah plastik di Kota Sorong digunakan beberapa variabel, antara lain: Pengetahuan penduduk/ rumah tangga dan pemilik usaha tentang sampah,Sikap penduduk/rumah tangga dan pemilik usaha dalam mengelola sampah, Perilaku penduduk/ rumah tangga dan pemilik usaha dalam mengelola sampah, Aktivitas Administrator Pemerintahan dalam pengelolaan sampah (kajian, sosialisasi, alokasi dana, dll),Dukungan faktor eksternal kepada administrator pemerintahan.

Analisa data yang digunakan dalam penelitian ini terbagi dalam 2 (dua) bentuk dan tahapan, yakni analisa tingkat timbulan sampah dan pencemaran serta analisis deskriptif kualitatif tentang lasti-faktor yang berpengaruh terhadap banyaknya sampah botol lastic di Kota Sorong.

\section{HASIL DAN PEMBAHASAN}

\section{Pengelolaan Sampah}

Proses pengelolaan sampah botol plastik air mineral pada dasarnya dikelola oleh pemerintah, masyarakat dan pihak swasta. Berikut ini penjabaran pengelolaan sampah botol air mineral:

\section{Pengelolaan oleh pihak pemerintah.}

Pengelolaan persampahan yang dikelola oleh pemerintah daerah adalah sistem pengelolaan sampah secara terpadu. Sistem pengelolaan sampah terpadu ini secara spesifik dikelola oleh Instansi Pemerintah Kota Sorong dengan agenda terbesar yaitu menyediakan sarana dan prasarana pengelolaan sampah yang memadai serta menciptakan alur/pola penanganan 
sampah yang tepat, sehingga volume sampah yang timbul di Kota Sorong setiap harinya dapat dikelola dan diatasi dengan baik.

Hal ini sesuai dengan fenomena yang banyak terjadi dan dilakukan oleh pemerintah di berbagai kota yang terdapat di negara-negara berkembang, yang lebih banyak disibukkan oleh berbagai aktifitas yang berhubungan dengan pengumpulan dan pembersihan sampah secara tradisional. Sedangkan untuk negara-negara maju sudah berfikir untuk pengubahan sampah menjadi sumber energi dan bahan daur ulang lainnya. Salah satu negara yang hampir serupa dengan Indonesia, dimana pemerintah di kota-kota yang terdapat di negara tersebut memiliki karakteristik aktifitas yang sama adalah negara Tanzania (Mungure, 2008). Sehingga perusahaan pengelola sampah bahkan memiliki fungsi untuk melakukan pengumpulan sampah.

Ada beberapa hal yang sudah dicapai oleh pemerintah Kota Sorong dalam pengelolaan persampahan, antara lain:

1. Sudah adanya aturan/regulasi yang mendukung kegiatan pengelolaan persampahan di Kota Sorong, yaitu: Perda No 14 Tahun 2012 tentang retribusi pelayanan persampahan/ kebersihan, dan Perda No 15 Tahun 2013 tentang pengelolaan sampah di Kota Sorong;

2. Telah hampir meratanya fasilitasfasilitas atau infrastruktur pengelolaan sampah di berbagai wilayah Kota Sorong, seperti TPS, dll

3. Sudah ada pola/alur pengelolaan sampah yang jelas, walaupun masih harus disempurnakan lagi sehingga prosesnya bisa lebih efisien.

Sedangkan beberapa hal yang masih harus dioptimalkan lagi oleh
Pemerintah Kota Sorong dalam hal pengelolaan sampah antara lain:

1. Peningkatan sosialisasi terhadap berbagai regulasi dan kebijakan serta perencanaan di bidang pengeloaan sampah terhadap khalayak umum;

2. Peningkatan pengetahuan aparat pemerintah dalam hal pengelolaan sampah, melalui berbagai penelitian atau studi yang langsung menyentuh permasalahan persampahan di masyarakat;

3. Perancangan anggaran yang tepat sasaran dan memadai dalam pengelolaan sampah;

4. Pemberdayaan masyarakat dan sektor bisnis dalam mengelola sam-pah di Kota Sorong.

\section{Pengelolaan Sampah Botol Air Mineral Oleh Pihak Masyarakat (Individu)}

Pengelolaan sampah secara individu oleh masyarakat baik rumah tangga maupun pemilik usaha sudah secara mandiri dilakukan. Hal ini seiring dengan meningkatnya pengetahuan masyarakat terhadap berbagai hal tentang pengelolaan persampahan, seperti dampak yang akan ditimbulkan oleh sampah, bagaimana memilah dan menggolongkan sampah, serta pentingnya penggunaan kembali barang-barang yang masih bisa dipakai namun berpotensi menjadi sampah (reusable).

Beberapa hal yang masih perlu dilakukan terkait dengan penanganan sampah yang dilakukan oleh masyarakat (individu):

a. Memberikan fasilitas pembuangan sampah yang spesifik sesuai dengan jenis sampah di tempat-tempat umum. Serta mengkampanyekan/ mensosialisasikan kegiatan pemilahan sampah kepada masyarakat umum. Sehingga masyarakat yang belum mengetahui menjadi tahu, dan yang sudah tahu akan termotivasi 
untuk melakukan pemilahan sampah karena telah terfasilitasi dengan baik;

b. Melakukan penertiban pelaksanaan pengelolaan sampah yang dilakukan masyarakat secara lebih serius, seperti memberikan denda terhadap masyarakat yang membuang sampah sembarangan di pantai, sungai, jalan, dll;

c. Mengajak masyarakat yang telah memahami pentingnya kegiatan dari bank sampah untuk ikut berpartisipasi dalam mengurangi sampah, khususnya sampah plastik. Sehingga masyarakat tidak sekedar paham pentingnya pengelolaan sampah yang baik, namun juga ikut andil dalam mengurangi sampah yang ada di Kota Sorong.

\section{Pengelolaan Sampah Plastik Oleh Pihak Swasta Melalui Bank Sampah}

Pengeloaan sampah di Kota

Sorong juga ada yang dilakukan oleh pihak swasta. Salah satunya adalah yang dilakukan oleh Yayasan Misool Baseftin dibawah pengawasan Misool Eco Resort bersama Yayasan Anak Sehat Persada yang pada Februari 2014 membangun sebuah program daur ulang sampah yang sekarang kita kenal sebagai Bank Sampah Sorong Raya. Bank Sampah Sorong Raya berdiri sebagai perwujudan kepedulian akan menciptakan lingkungan yang bersih.

Hingga tahun 2016 akhir sudah ada hampir 2800 nasabah yang tercatat yang bergabung di 56 Unit mandiri yang tersebar di Kota Sorong, Aimas, Raja Ampat Utara dan Misool. Dari ke 56 unit yang ada tersebut, Bank Sampah Sorong Raya dengan 22 karyawannya berhasil mengumpulkan kurang lebih 700 ton sampah dalam tahun 2016, dan mengolah secara mandiri 100 ton sampah yang dikumpulkan. Hasil olahan sampah kemudian di jual untuk diolah lebih lanjut oleh pabrik plastik di Jawa Timur.

Bank Sampah Sorong Raya mengumpulkan berbagai jenis sampah, dalam garis besar sampah yang dikumpulkan dapat dikelompokkan menjadi 3 jenis yaitu, kertas, plastik, dan logam.

Untuk plastik, jenis sampah yang BSSR kumpulkan antara lain:

1. PET, plastik berlogo daur ulang nomor 1 yang kami ambil adalah segala jenis plastik PET baik bening maupun warna

2. HDPE, plastik berlogo daur ulang nomor 2 yang kami ambil adalah segala jenis plastik seperti jerigen, botol sabun, botol shampoo, botol oli, dan sejenisnya

3. LDPE, plastik berlogo daur ulang nomor 4 yang kami ambil adalah plastik LDPE yang diambil hanyalah botol infus dan tutup botol

4. PP, plastik berlogo daur ulang nomor 5 yang kami ambil adalah segala jenis plastik PP baik yang digunakan untuk minuman gelas kemasan, peralatan makan, kursi dan meja plastik, ember, dan sejenisnya

5. Others, plastik berlogo daur ulang nomor 7 yang kami ambil adalah galon. Untuk ABS seperti helm dan kap motor sementara BSSR tidak mengumpulkannya terlebih dahulu

Sehingga secara keseluruhan jika dilihat secara persentase maka jumlah sampah yang terkumpul pada tahun 2015 dan 2016 adalah seperti gambar 1 . Dimana secara proporsi besarnya sampah pada masing-masing jenis lebih variatif dan proporsi yang hampir seimbang terkumpul pada tahun 2016. Sedangkan di tahun 2015 lebih banyak didominasi oleh sampah PET. 


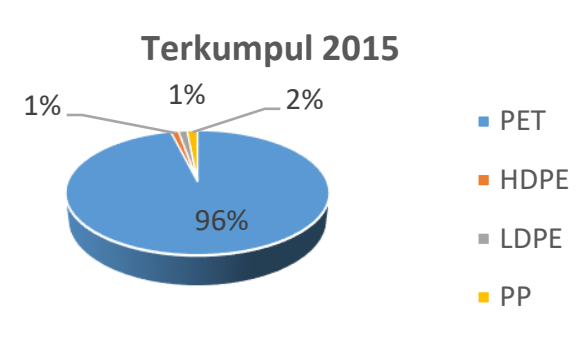

Terkumpul 2016

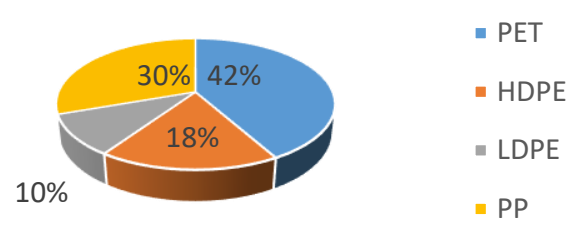

Gambar 1. Banyaknya Sampah Plastik Yang Terkumpul Menurut Jenisnya Di Tahun 2015 - 2016

Kemudian untuk jumlah plastik yang diproduksi dari masing-masing jenis sampah juga mengalami perubahan proporsi dari tahun $2015 \mathrm{ke}$ tahun 2016. Dimana secara persentase jumlah plastik dari sampah PET menurun dari $71 \%$ menjadi $56 \%$ dan ada peningkatan di jumlah plastik dari sampah selain PET menjadi lebih besar dibanding dengan tahun 2015 (Gambar 2).
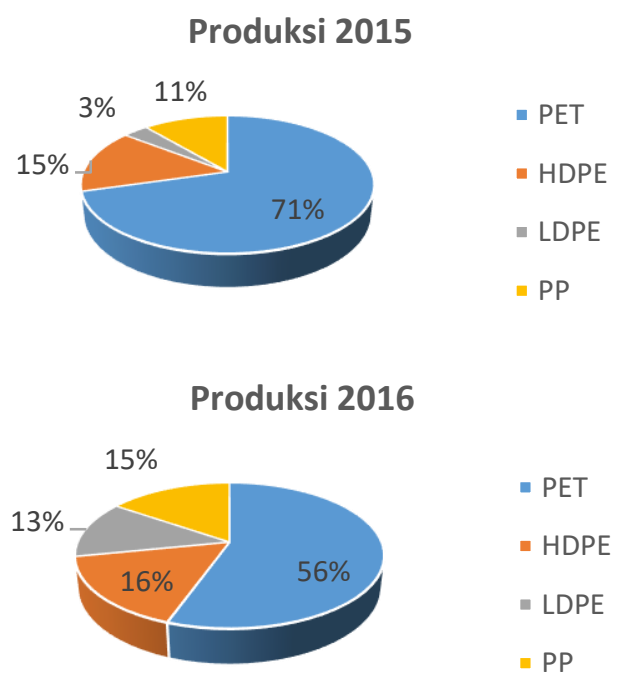

Gambar 2. Banyaknya Produksi

Sampah Plastik Menurut Jenisnya

Tahun 2015 - 2016
Faktor-faktor apa saja yang berpengaruh terhadap banyaknya sampah plastik botol air mineral yang disetor ketempat pengelolaan sampah plastik di Kota Sorong

\section{Pengetahuan Masyarakat Rumah Tangga}

Dari gambar 3dapat dilihat bahwa mayoritas masyarakat yang tinggal dalam rumah tangga, yaitu sebanyak $70 \%$ menyatakan bahwa sampah didefinisikan sebagai sesuatu yang tidak terpakai dan harus dibuang. Selanjutnya untuk gambar 4 tentang penggolongan jenis sampah, terlihat bahwa pemahaman masyarakat cukup baik, yaitu $65 \%$ atau mayoritas menjawab tahu dengan jenis penggolongan sampah organik dan anorganik. Dari sudut pandang dampak secara negatif masyarakat secara mayoritas, yaitusebanyak 94\% menyatakan bahwa sampah menyebabkan penyakit dan mengurangi keindahan. Sedangkan hanya 6\% dari mereka yang melihat secara lebih dalam yaitu keberadaan sampah mencerminkan status sosial yang rendah dan tempat yang kumuh. Namun, jika dilihat dari sisi positifnya, 92\% masyarakat setuju jika keberadaan sampah dapat menghasilkan uang jika diolah kembali.

Sedangkan untuk kepemilikan masyarakat terhadap tempat pembuangan sampahdidapat informasi bahwa sebanyak $71 \%$ masyarakat memiliki tempat pembuangan sampah pada tempat tinggalnya dan mereka dapat menunjukkannya, sedangkan sebanyak 8\% memiliki namun tidak dapat menunjukkan dengan berbagai alasan dan sisanya sebanyak $21 \%$ mengaku tidak memiliki tempat pembuangan sampah di tempat tinggalnya. Hasil ini cukup positif, artinya mayoritas masyarakat sadar akan pentingnya menyediakan tempat khusus untuk 
mengelola sampah di tempat tinggalnya. Namun, yang perlu untuk diupayakan adalah bahwa masih ada sebanyak $21 \%$ dari masyarakat yang butuh support untuk memiliki tempat pembuangan di tempat tinggalnya sendiri.

Keadaan ini masih lebih baik jika dibandingkan beberapa kota di Republik Ghana, dimana mereka bahkan tidak mau menyediakan tempat pembuangan sampah ditempat tinggalnya sendiri. dalam salah satu penelitian yang dilakukan oleh Essuman disebutkan bahwa sebagian besar atau lebih dari 40 persen penduduk di Kota Gbegbeyise, Glefe, dan Mamprobi tidak bersedia menyediakan tempat sampah di tempat tinggal mereka. Hal ini terjadi karena sebagian besar dari mereka lebih menyukai untuk membakar langsung sampah yang diproduksi oleh rumah tangganya masing-masing (Essuman, 2017).

Sedangkan untuk pengetahuan masyarakat tentang Pencemaran lingkungan akibat sampah. Mayoritas masyarakat yaitu sekitar $51 \%$ menganggap bahwa tingkat pencemaran di Kota Sorong masih biasa saja namun perlu penanganan yang tepat. Kemudian sekitar $28 \%$ menyatakan bahwa tingkat pencemaran sudah parah tetapi masih bisa dikendalikan, sedangkan $18 \%$ dari masyarakat mengatakan bahwa tingkat pencemaran sudah parah dan sulit untuk ditanggulangi lagi. Sisanya sebanyak $2 \%$ mengatakan biasa saja dan belum terlalu penting untuk dipikirkan dan $1 \%$ menyatakan tidak tahu.

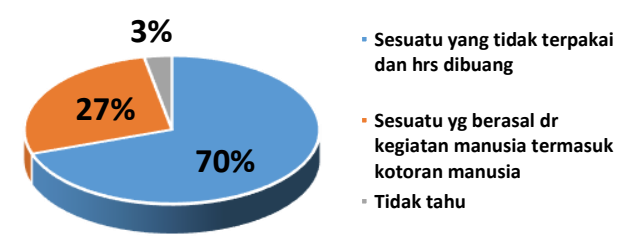

Gambar 3. Pengetahuan Masyarakat

Tentang Definisi Sampah yang

diketahui oleh mereka

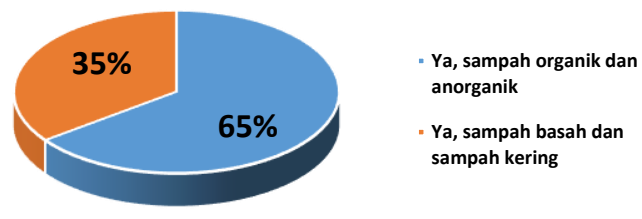

Gambar 4. Pengetahuan Masyarakat

Terkait Penggolongan Jenis-jenis Sampah

Pengetahuan Masyarakat Tentang Jenis Sampah yang Menjadi Sumber Pencemaran. Sebanyak $78 \%$ dari masyarakat sepakat bahwa jenis sampah yang paling banyak menjadi sumber pencemaran adalah barang anorganik dari plastik. Kemudian sekitar 17\% menyatakan bahwa yang paling banyak adalah sampah organik makanan. Sedangkan sisanya sebanyak $2 \%$ mamilih sampah organik lainnya dan $2 \%$ sampah anorganik lainnya serta $1 \%$ sampah organik dari tanaman. Sehingga bisa disimpulkan bahwa di Kota Sorong sampah terbanyak berdasarkan pandangan masyarakat adalah sampah anorganik dari plastik. Selanjutnya, jika dilihat lebih detail lagi maka sampah botol minuman/air mineral menempati urutan pertama pilihan masyarakat untuk barang dari plastik yang paling banyak mencemari lingkungan, yaitu sebanyak $71 \%$ masyarakat memilihnya. Sedangkan sebanyak $18 \%$ memilih bungkus/kemasan produk. Kemudian sisanya sebanyak 7\% memilih tas plastik/kresek dan $4 \%$ memilih lainnya. 


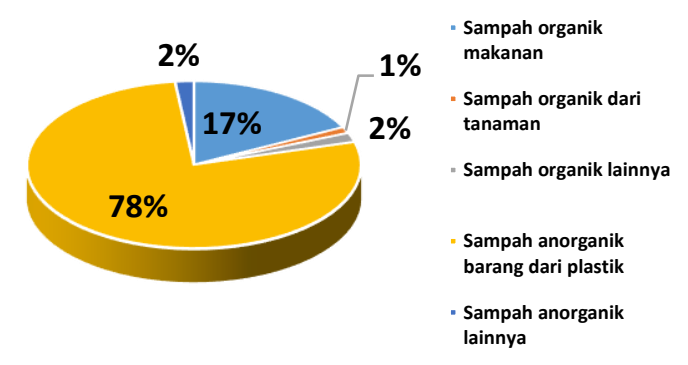

Gambar 5. Pengetahuan Masyarakat Tentang Jenis Sampah yang Menjadi Sumber Pencemaran

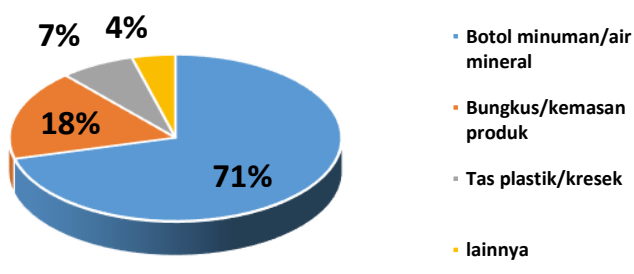

Gambar 6. Pengetahuan Masyarakat tentang Sumber dari Jenis Sampah Anorganik Plastik yang Terbanyak

Kemudian jika dilihat dari pengetahuannya tentang adanya Informasi/sosialisasi dari Pemerintah Terkait Perda Pengelolaan Sampah, maka hasilnya adalah seperti gambar berikut.

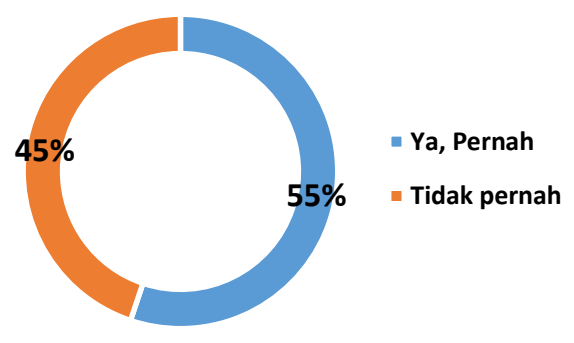

Gambar 7. Pengetahuan Masyarakat tentang adanya Informasi/sosialisasi dari Pemerintah Terkait Perda Pengelolaan Sampah

Sekitar $55 \%$ masyarakat menyatakan pernah mengetahui adanya sosialisasi dari pemerintah terkait adanya Peraturan Daerah (PERDA) tentang pengelolaan sampah. Sedangkan sisanya sekitar $45 \%$ tidak pernah mendengar. Sedangkan untuk program bank sampah dan keberadaannya, maka sekitar 37\% masyarakat Kota Sorong menyatakan pernah mendengar sosialisasi melalui televisi, sedangkan sebanyak 24\% mendengar dari berita lisan yang beredar di masyarakat. Kemudian sebanyak 17\% mendengar dari koran dan $10 \%$ mendengar dari radio. Namun, masih ada juga sekitar $12 \%$ dari masyarakat yang mengaku belum pernah mendengar sosialisasi.

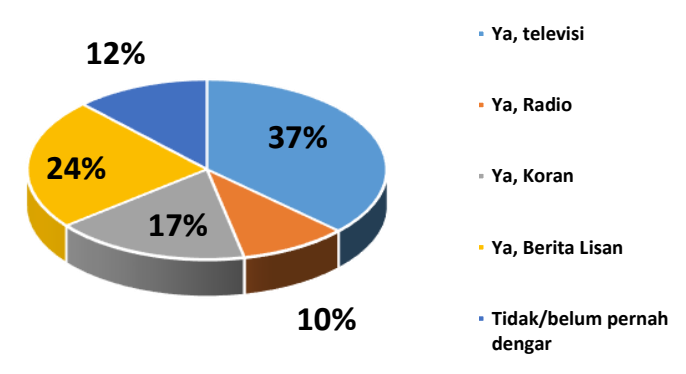

Gambar 8. Pengetahuan Masyarakat

Tentang Adanya Informasi Terkait Keberadaan Bank Sampah serta Sumber Informasi Tersebut

\section{Sikap Masyarakat Tentang Pengelo- laan Sampah}

Tentang keberadaan tempat pembuangan sampah, sikap masyarakat sangat positif. Hal ini bisa dilihat dari grafik dibawah sebanyak $45 \%$ masyarakat menyatakan sangat setuju dan sebanyak $47 \%$ menyatakan setuju. Sehingga diatas $90 \%$ masyarakat menyatakan sikap yang positif terhadap pernyataan ini. Kemudian pernyataan tentang pemisahan sampah organik dan anorganik, secara mayoritas yaitu sebanyak $98 \%$ menyatakan sangat setuju dan setuju. Selanjutnya untuk ajakan tentang usaha pemisahan sampah yang dilakukan oleh rumah tangga sebanyak 
$60 \%$ masyarakat menyatakan setuju dan $30 \%$ masyarakat menyatakan sangat setuju.

Kemudian sikap masyarakat terhadap pernyataan jika sampah rumah tangga harus dikurangi, sekitar 23\% masyarakat menyatakan sangat setuju dan 58\% masyarakat menyatakan setuju terhadap pernyataan bahwa masyarakat harus mengurangi produksi sampah dalam rumah tangga. Selain mengurangi volume produksi sampah, penggunaan barang-barang daur ulang juga bisa menjadi solusi untuk memperkecil banyaknya sampah yang terdapat di lingkungan kita. Secara mayoritas, yaitu sekitar $61 \%$ masyarakat menyatakan setuju untuk menggunakan barangbarang daur ulang, bahkan $16 \%$ masyarakat mengaku sangat setuju terhadap langkah ini. Namun diantara mereka masih terdapat sekitar $7 \%$ yang kurang setuju dan $6 \%$ yang tidak setuju.

Sekalipun masih ada sekitar $23 \%$ dari masyarakat yang kurang setuju, tidak setuju dan ragu-ragu dalam menggunakan bahan daur ulang, namun hanya sekitar $6 \%$ yang ragu-ragu, kurang setuju dan tidak setuju jika sampah memang sebaiknya bisa didaur ulang. Hal ini menunjukkan sikap yang positif, dimana hampir secara keseluruhan, atau sekitar 93\% masyarakat menyetujui adanya langkah daur ulang terhadap sampah.

Penggunaan barang-barang yang dianggap menjadi sampah, namun sebenarnya masih bisa digunakan kembali baik oleh orang yang sama maupun orang lain juga merupakan salah satu langkah untuk mengurangi volume sampah yang tersebar di lingkungan. Namun, langkah ini hanya disetujui oleh sekitar $90 \%$ masyarakat, dan sisanya sebanyak $10 \%$ masih raguragu, kurang setuju dan tidak setuju terhadap langkah tersebut.
Secara mayoritas masyarakat setuju terhadap pendapat yang menyatakan jika sampah anorganik seharusnya disetor ke bank sampah. Karena bank sampah juga merupakan solusi untuk mengurangi jumlah sampah di masyarakat, dan juga bahkan sangat menguntungkan bagi masyarakat karena ada income secara finansial yang bisa diperoleh dari hal tersebut. Sehingga sekitar 91\% masyarakat menyetujui hal ini, dan sisanya sebanyak $9 \%$ adalah ragu-ragu, kurang setuju dan tidak setuju.

Jika dilihat dari ulasan tentang sikap masyarakat diatas, secara keseluruhan sikap masyarakat Kota Sorong hampir selaras dengan sikap masyarakat yang ada di daerah Daerah Istimewa Yogyakarta. Dimana jika dilihat dari sikapnya sebanyak 90,9\% masyarakat Yogyakarta memiliki sikap yang baik, sedangkan untuk sikap yang kurang baik dalam mengelola sampah hanya $9,1 \%$ saja (Mulasari, 2012).

\section{Perilaku Masyarakat dalam Pengelo- laan Sampah}

Setelah dilihat dari sudut pandang sikap masyarakat terhadap pendapatpendapat positif dalam rangka pengelolaan sampah, dibawah ini akan dielaborasi lebih lanjut tentang perilaku sehari-hari masyarakat dalam mengelola sampah di tempat tinggalnya.

Secara mayoritas atau sekitar $44 \%$ masyarakat menghasilkan sampah sekitar 1 - $2 \mathrm{~kg}$ perhari, sedangkan 39\% memproduksi sampah kurang dari $1 \mathrm{~kg}$ perhari, dan sisanya sebanyak $17 \%$ menghasilkan lebih dari $2 \mathrm{~kg}$ sampah perhari. Jika dilihat dari repetitifnya sekitar $28 \%$ dari masyarakat yang membuang sampah $1-2$ kali dalam sehari dan sekitar 7\% yang bahkan membuang sampah lebih dari 2 kali dalam sehari. Tentunya hal ini akan 
membuat volume sampah yang dihasilkan semakin meningkat.

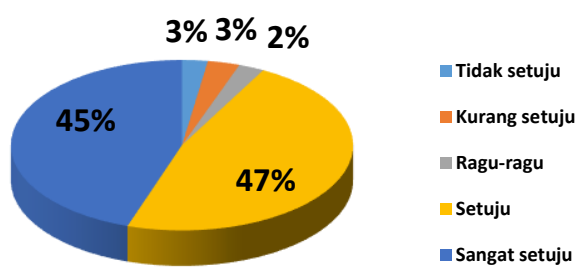

Gambar 9. Sikap Masyarakat Terhadap

Pernyataan Jika Tiap Rumah Harus

Punya Tempat Pembuangan Sampah

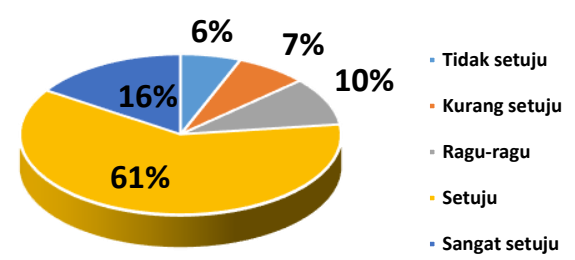

Gambar 10. Sikap Masyarakat Terhadap

Pernyataan Jika Rumah Tangga

Memakai Barang Daur Ulang

Kemudian jika dilihat dari kebiasaan masyarakat dalam membuang sampah, mayoritas masyarakat Kota Sorong cenderung megandalkan keberadaan TPS yang ada di lingkungan tempat tinggal mereka, sekitar $65 \%$ masyarakat memiliki perilaku seperti ini. Hal ini diduga akibat keterbatasan lahan tempat tinggal sehingga mereka tidak dapat membuat lobang tempat sampah di tempat tinggalnya masingmasing. Mayarakat yang memiliki lobang tempat sampah hanya sekitar $24 \%$ saja. Sedangkan yang lebih memprihatinkan masih ada sekitar $11 \%$ masyarakat yang membuang sampah baik di pantai, sungai dan lainnya.

Sebagian besar masyarakat tidak melakukan pemisahan sampah menurut jenisnya, setidaknya hal ini dilakukan oleh sekitar 64\% rumah tangga. Sedangkan yang melakukan pemisahan hanya sekitar $34 \%$ saja dan sisanya mengaku tidak tahu. Perilaku masyarakat yang baik dalam memilah sampah memang terbukti hanya dilakukan oleh sedikit masyarakat Kota Sorong. Hal ini juga terjadi di Kabupaten Sleman Provinsi Yogyakarta, dimana hanya terdapat $45,5 \%$ masyarakatnya saja yang memiliki perilaku baik dalam mengolah sampah, sedangkan sebanyak $54,5 \%$, atau lebih banyak yang malah kurang baik dalam mengolah sampah (Surahma, 2012). Hal ini menunjukkan bahwa walaupun pengetahuan dan sikap masyarakat sudah baik, belum tentu perilaku mereka juga sinergi dengan sikap dan pengetahuan tersebut.

Sedangkan untuk perilaku masyarakat di beberapa Kota di Republik Ghana dalam memilah sampah malah lebih buruk jika dibandingkan warga Kota Sorong. Tercatat di tiga kota di Ghana yaitu Mamprobi, Glefe dan Gbegbeyise sebanyak hampir 70 persen masyarakatnya tidak bersedia melakukan pemilahan sampah berdasarkan jenis-jenisnya (Essuman, 2017).

Sekitar 62\% masyarakat manyatakan tidak pernah memanfaatkan kembali sampah botol plastik yang mereka hasilkan. Sedangkan sisanya sekitar 38\% mengaku pernah memanfaatkan sampah botol plastik tersebut. Kemudian rumah tangga yang mengaku pernah memanfaatkan bank sampah dalam mengelola sampah yang dihasilkan hanya sekitar $21 \%$. Sedangkan yang tidak pernah memanfaatkan keberadaan bank sampah adalah sebanyak $71 \%$, dan sisanya sebanyak 8\% mengaku tidak tahu. Kurangnya sosialisasi diduga menjadi salah satu penyebab ketidaktahuan atau bahkan kurangnya motivasi masyarakat dalam memanfaatkan bank sampah. 


\section{Tingkat Pengetahuan Tentang Sampah dari Pelaku Usaha}

Secara empirisdiperoleh informasi bahwa mayoritas pemilik usaha/ perusahaan, yaitu sebanyak 57\% menyatakan bahwa sampah didefinisikan sebagai sesuatu yang tidak terpakai dan harus dibuang. Sedangkan sebanyak $43 \%$ mendefinisikan sebagai sesuatu yang berasal dari kegiatan manusia termasuk kotoran manusia.

Selanjutnya untuk pertanyaan tentang penggolongan jenis sampah, terlihat bahwa pemahaman pemilik usaha/perusahaan cukup baik, yaitu $62 \%$ atau mayoritas menjawab tahu dengan jenis penggolongan sampah organik dan anorganik. Sedangkan sisanya sebanyak $38 \%$ menggolongkan kedalam sampah basah dan kering.

Persoalan tentang sampah menyisakan dampak dari hal tersebut, baik dilihat dari sisi positif maupun negatif. Dari sudut pandang dampak secara negatif pemilik usaha/perusahaan secara mayoritas, yaitu sebanyak $95 \%$ menyatakan bahwa sampah menyebabkan penyakit dan mengurangi keindahan. Sedangkan hanya 5\% dari mereka yang melihat secara lebih dalam yaitu keberadaan sampah mencerminkan status sosial yang rendah dan tempat yang kumuh.

Namun, jika dilihat dari sisi positifnya, $95 \%$ pemilik usaha/ perusahaan setuju jika keberadaan sampah dapat menghasilkan uang jika diolah kembali, sedangkan kelompok masyarakat yang pesimis dan menyatakan bahwa sampah tidak punya dampak positif hanya sekitar 5\% saja.

Jawaban pemilik usaha/perusahaan terhadap pertanyaan-pertanyaan dibawah ini untuk mengelaborasi tentang kepemilikan terhadap sarana pembuangan sampah serta pengetahuan masyarakat tentang sarana/fasilitas yang disediakan baik oleh pemerintah maupun swadaya masyarakat dalam rangkauntuk pengelolaan sampah.

Kemudian didapat informasi juga bahwa sebanyak $81 \%$ pemilik usaha/ perusahaan memiliki tempat pembuangan sampah pada tempat tinggalnya dan mereka dapat menunjukkannya, sedangkan sebanyak 5\% memiliki namun tidak dapat menunjukkan dengan berbagai alasan dan sisanya sebanyak $14 \%$ mengaku tidak memiliki tempat pembuangan sampah di tempat tinggalnya. Namun, yang perlu untuk diupayakan adalah bahwa masih ada sebanyak $19 \%$ dari masyarakat yang butuh support untuk memiliki tempat pembuangan di tempat usahanya sendiri.

Sebanyak $76 \%$ pemilik usaha/ perusahaan mengetahui dan dapat menunjukkan dengan benar keberadaan Tempat Pembuangan Sampah Sementara (TPS) di lingkungan tempat tinggalnya. Sisanya sebanyak $24 \%$ mengetahui namun tidak dapat menunjukkan dengan benar letak TPS.

Kemudian untuk masalah keberadaan bank sampah terdekat dengan lingkungan tempat tinggal pemilik usaha/perusahaan, hanya sebanyak $28 \%$ yang tahu dan dapat menunjukkan dengan tepat. Sedangkan sebanyak $29 \%$ Mengaku tahu namun tidak menunjukkan dengan tepat posisi bank sampah yang dimaksud, dan sisanya sebanyak 43\% mengaku tidak tahu dimana letak bank sampah.

Pada bagian ini akan dielaborasi berbagai hal terkait pandangan pemilik usaha/perusahaan terhadap tingkat pencemaran di Kota Sorong beserta halhal yang menyebabkan pencemaran tersebut.

Beberapa pemilik usaha/perusahaan yaitu sekitar 33\% menganggap bahwa tingkat pencemaran di Kota Sorong masih biasa saja namun perlu penanganan yang tepat. Kemudian sekitar $48 \%$ menyatakan bahwa tingkat 
pencemaran sudah parah tetapi masih bisa dikendalikan, sedangkan $14 \%$ dari pemilik usaha/perusahaan mengatakan bahwa tingkat pencemaran sudah parah dan sulit untuk ditanggulangi lagi. Sisanya sebanyak 5\% menyatakan tidak tahu.

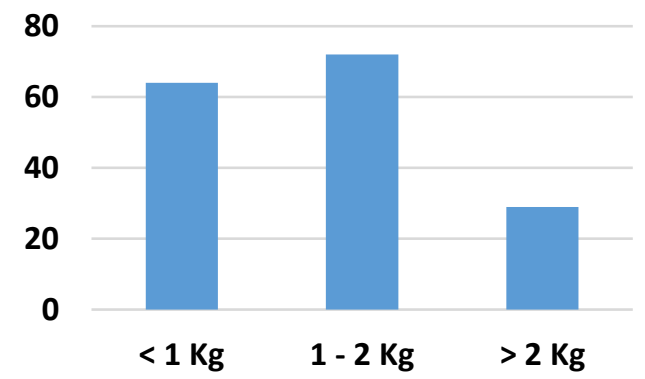

Gambar 11. Banyaknya Sampah yang Diproduksi Rumah Tangga dalam Sehari

Lebih dari 2 kali

1 - 2 kali

$\begin{array}{llll}0 & 50 & 100 & 150\end{array}$

Gambar 12. Frekuensi Rumah Tangga Membuang Sampah dalam Sehari

Sebanyak $67 \%$ dari pemilik usaha/perusahaan sepakat bahwa jenis sampah yang paling banyak menjadi sumber pencemaran adalah barang anorganik dari plastik. Kemudian sekitar 19\% menyatakan bahwa yang paling banyak adalah sampah organik makanan. Sedangkan sisanya sebanyak $14 \%$ mamilih sampah organik lainnya. Sehingga bisa disimpulkan bahwa di Kota Sorong sampah terbanyak berdasarkan pandangan pemilik usaha/perusahaan adalah sampah anorganik dari plastik.

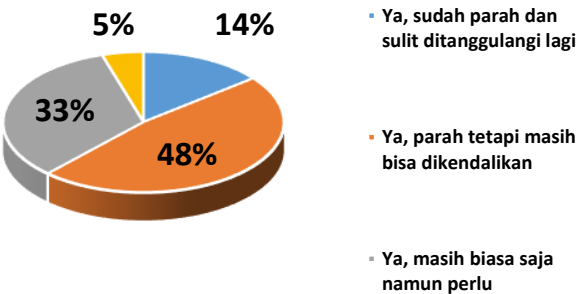

Gambar 13. Pengetahuan Pelaku Usaha Tentang Tingkat Pencemaran Akibat Sampah di Kota Sorong

Sampah botol minuman/air mineral menempati urutan pertama pilihan pemilik usaha/perusahaan untuk barang dari plastik yang paling banyak mencemari lingkungan, yaitu sebanyak 57\% masyarakat memilihnya. Sedangkan sebanyak 33\% memilih bungkus/ kemasan produk. Kemudian sisanya sebanyak 5\% memilih tas plastik/kresek dan 5\% memilih lainnya.

Sekitar $62 \%$ pemilik usaha/ perusahaan menyatakan pernah mengetahui adanya sosialisasi dari pemerintah terkait adanya Peraturan Daerah (PERDA) tentang pengelolaan sampah. Sedangkan sisanya sekitar $38 \%$ tidak pernah mendengar. Hal ini harusnya menjadi PR buat pemerintah daerah khususnya untuk lebih mensosialisasikan PERDA tersebut.

Terkait keberadaan bank sampah, sekitar $19 \%$ pemilik usaha/perusahaan di Kota Sorong menyatakan pernah mendengar sosialisasi melalui televisi, sedangkan sebanyak 34\% mendengar dari berita lisan yang beredar di masyarakat. Kemudian sebanyak $14 \%$ mendengar dari koran dan 14\% mendengar dari radio. Namun, masih ada juga sekitar $19 \%$ dari pemilik usaha/perusahaan yang mengaku belum pernah mendengar sosialisasi.

\section{Sikap Pemilik Usaha/Perusahaan Dalam Pengelolaan Sampah}

Tentang keberadaan tempat pembuangan sampah, sikap pemilik 
usaha/perusahaan sangat positif. Sebanyak $43 \%$ masyarakat menyatakan sangat setuju dan sebanyak $38 \%$ menyatakan setuju. Sehingga diatas $81 \%$ pemilik usaha/perusahaan menyatakan sikap yang positif terhadap pernyataan ini.

Kemudian pernyataan tentang pemisahan sampah organik dan anorganik, secara mayoritas yaitu sebanyak 95\% menyatakan sangat setuju dan setuju. Hal ini menunjukkan pemilik usaha/perusahaan sadar akan pentingnya pemisahan jenis-jenis sampah untuk mendukung program daur ulang sampah.

Kemudian untuk ajakan tentang
usaha pemisahan sampah yang dilakukan oleh rumah tangga sebanyak $62 \%$ masyarakat menyatakan setuju dan $33 \%$ masyarakat menyatakan sangat setuju. Sedangkan sisanya sebanyak 5\% masih ragu-ragu.

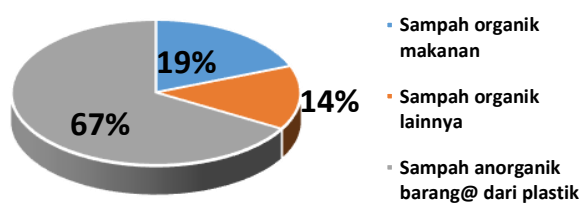

Gambar 14. Pengetahuan Pelaku Usaha

Tentang Jenis Sampah yang Menjadi Sumber Pencemaran

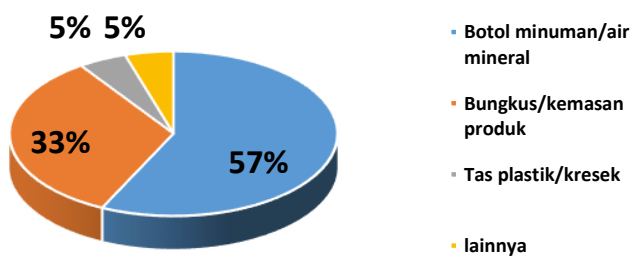

Gambar 15. Pengetahuan Pelaku Usaha Tentang Sumber Jenis Sampah Anorganik Plastik Terbanyak

Sekitar 19\% pemilik usaha/ perusahaan menyatakan sangat setuju dan 57\% masyarakat menyatakan setuju terhadap pernyataan bahwa masyarakat harus mengurangi produksi sampah dalam rumah tangga. Hal ini merupakan signal positif dari pemilik usaha/perusahaan yang semakin peduli terhadap lingkungan, namun diantara mereka masih ada sekitar 9\% yang merasa kurang setuju dan 5\% yang bahkan tidak setuju dengan pendapat ini serta $10 \%$ masih ragu-ragu.

Selain mengurangi volume produksi sampah, penggunaan barangbarang daur ulang juga bisa menjadi solusi untuk memperkecil banyaknya sampah yang terdapat di lingkungan kita. Secara mayoritas, yaitu sekitar $38 \%$ pemilik usaha/perusahaan menyatakan setuju untuk menggunakan barang-barang daur ulang, bahkan 24\% masyarakat mengaku sangat setuju terhadap langkah ini. Namun diantara mereka masih terdapat sekitar 10\% yang kurang setuju dan 14\% yang tidak setuju.

Tidak terdapat pemilik usaha/perusahaan yang merasa tidak setuju, kurang setuju maupun ragu-ragu dalam pernyataan bahwa sampah seharusnya bisa didaur ulang. Hal ini menunjukkan sikap yang positif, dimana secara keseluruhan, yaitu 100\% masyarakat menyetujui adanya langkah daur ulang terhadap sampah.

Penggunaan barang-barang yang dianggapmenjadi sampah, namun sebenarnya masih bisa digunakan kembali baik oleh orang yang sama maupun orang lain juga merupakan salah satu langkah untuk mengurangi volume sampah yang tersebar di lingkungan. Namun, langkah ini hanya disetujui oleh sekitar $90 \%$ pemilik usaha/perusahaan, dan sisanya sebanyak $10 \%$ masih ragu-ragu, kurang setuju dan tidak setuju terhadap langkah tersebut.

Secara mayoritas pemilik usaha/perusahaan setuju terhadap pendapat yang menyatakan jika sampah anorganik seharusnya disetor ke bank 
sampah. Karena bank sampah juga merupakan solusi untuk mengurangi jumlah sampah di masyarakat, dan juga bahkan sangat menguntungkan bagi masyarakat karena ada income secara finansial yang bisa diperoleh dari hal tersebut. Sehingga sekitar $90 \%$ masyarakat menyetujui hal ini, dan sisanya sebanyak $10 \%$ adalah raguragu.

Jika dilihat dari ulasan tentang sikap masyarakat diatas, secara keseluruhan pemilik usaha/perusahaan di Kota Sorong memiliki sikap yang positif terhadap permasalahan sampah, bahkan cenderung menyetujui terhadap langkah-langkah positif yang bisa diambil untuk menyelesaikan masasalah sampah ini. Hal ini seharusnya menjadi support bagi pihak pemerintah maupun swasta yang berkecimpung di masalah pengelolaan sampah, untuk dapat lebih efektif lagi dalam melaksanakan perannya dalam mengurangi volume sampah yang beredar di lingkungan masyarakat.

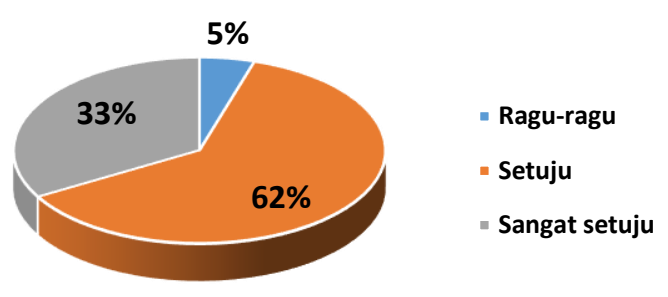

Gambar 16. Sikap Pelaku Usaha Terhadap Pemisahan Sampah Menurut Jenisnya

\section{Perilaku Pemilik Usaha/Perusahaan dalam Pengelolaan Sampah}

\footnotetext{
Setelah dilihat dari sudut pandang sikap pemilik usaha/perusahaan terhadap pendapat-pendapat positif dalam rangka pengelolaan sampah, dibawah ini akan dielaborasi lebih
}

lanjut tentang perilaku sehari-hari masyarakat dalam mengelola sampah di tempat tinggalnya.

Secara mayoritas atau sekitar $61 \%$ pemilik usaha/perusahaan menghasilkan sampah sekitar lebih dari $2 \mathrm{~kg}$ perhari, sedangkan 19\% memproduksi sampah kurang dari $1 \mathrm{~kg}$ perhari, dan sisanya juga sebanyak 19\% menghasilkan antara 1 - $2 \mathrm{~kg}$ sampah perhari.

Terdapat sekitar $47 \%$ dari pelaku usaha yang membuang sampah 1 kali dalam sehari dan sekitar $28 \%$ yang membuang sampah antara 1-2 kali dalam sehari serta sisanya sekitar $25 \%$ membuang sampah lebih dari 2 kali dalam sehari. Tentunya hal ini akan membuat volume sampah yang dihasilkan semakin meningkat.

Kemudian jika dilihat dari kebiasaan masyarakat dalam membuang sampah, mayoritas pemilik usaha/ perusahaan di Kota Sorong cenderung megandalkan keberadaan TPS yang ada di lingkungan tempat tinggal mereka, sekitar $66 \%$ pemilik usaha/perusahaan memiliki perilaku seperti ini. Hal ini diduga akibat keterbatasan lahan tempat usaha sehingga mereka tidak dapat membuat lobang tempat sampah di tempat usahanya masing-masing. Pemilik usaha/perusahaan yang memiliki lobang tempat sampah hanya sekitar $24 \%$ saja. Sedangkan yang lebih memprihatinkan masih ada sekitar 10\% pemilik usaha/perusahaan yang membuang sampah baik di pantai, sungai dan lainnya. Hal ini tentunya menjadi catatan, khususnya Pemerintah Daerah untuk mengajak pemilik usaha/ perusahaan memanfaatkan TPS serta membangun fasilitas TPS di tempattempat yang masih belum ada TPS-nya.

Sebagian besar pemilik suaha/ perusahaan tidak melakukan pemisahan sampah menurut jenisnya, setidaknya hal ini dilakukan oleh sekitar $48 \%$ 
pemilik suaha/perusahaan. Sedangkan yang melakukan pemisahan hanya sekitar $43 \%$ saja dan sisanya mengaku tidak tahu. Sehingga bisa disimpulkan bahwa masih banyak pemilik suaha/ perusahaan yang belum termotivasi untuk melakukan pemisahan sampah, hal ini perlu dicari solusinya agar kedepan pemilik suaha/perusahaan semakin sadar pentingnya pemisahan sampah untuk memudahkan pengklasifikasian dalam proses daur ulang.

Sekitar $52 \%$ pemilik usaha/ perusahaan menyatakan tidak pernah memanfaatkan kembali sampah botol plastik yang mereka hasilkan. Sedangkan sisanya sekitar $48 \%$ mengaku pernah memanfaatkan sampah botol plastik tersebut. Hal ini tentunya harus mendapat perhatian khusus, karena menurut pendapat mayoritas pemilik usaha/perusahaan sampah botol plastik merupakan sampah anorganik yang paling banyak berkontribusi terhadap pencemaran lingkungan di Kota Sorong.

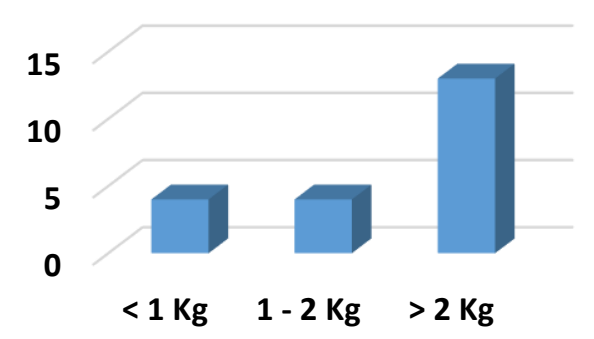

Gambar 17. Banyaknya Sampah yang dihasilkan Pelaku Usaha per Hari

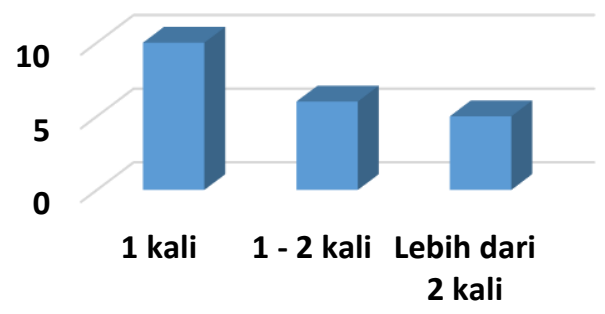

Gambar 18. Frekuensi Pelaku Usaha Membuang Sampah Per Hari
Pemilik usaha/perusahaan yang mengaku pernah memanfaatkan bank sampah dalam mengelola sampah yang dihasilkan hanya sekitar 5\%. Sedangkan yang tidak pernah memanfaatkan keberadaan bank sampah adalah sebanyak $86 \%$, dan sisanya sebanyak $9 \%$ mengaku tidak tahu. Kurangnya sosialisasi diduga menjadi salah satu penyebab ketidaktahuan atau bahkan kurangnya motivasi pemilik usaha/perusahaan dalam memanfaatkan bank sampah.

\section{Upaya Administrator Pemerintahan Dalam Melakukan Kajian atau Sosialisasi Tentang Pengelolaan Sampah Kepada Masyarakat}

Dalam melakukan pengelolaan sampah, sudah seharusnya pemerintah daerah melalui instansi terkait harus mengetahui letak permasalahan yang ada di masyarakat. Baik ditinjau dari sisi kelengkapan fasilitas pendukung dalam pengelolaan sampah maupun informasi tentang hal-hal yang menjadi penyebab/sumber terbesar produksi sampah di masyarakat. Selain itu sudah seyogyanya pula pemerintah daerah melakukan sosialisasi terhadap berbagai aturan maupun langkah-langkah atau program yang sedang dilaksanakan dalam kaitannya dengan pengelolaan sampah.

Secara empiris dapat diketahui bahwa ternyata hanya $62 \%$ dari administrator pemerintah tingkat kelurahan di Kota Sorong yang pernah melakukan kajian/identifikasi terhadap kebutuhan fasilitas pengelolaan sampah di masyarakat yang ada di wilayahnya. Sedangkan sisanya sebanyak $38 \%$ belum pernah melaksanakan. Kemudian yang pernah melakukan kajian atau penelitian yang berkaitan dengan informasi tentang sumber sampah yang ditimbulkan masyarakat hanya sekitar 
$38 \%$, sedangkan sisanya sebanyak $62 \%$ belum pernah melaksanakan.

Selanjutnya sekitar $77 \%$ dari administrator pemerintah tingkat kelurahan mengaku pernah melakukan sosialisasi terkait fasilitas pengelolaan sampah yaitu bank sampah ke masyarakat. Sedangkan sisanya sekitar 23\% menyatakan diri belum pernah melaksanakan sosialisasi terkait hal tersebut. Untuk masalah sosialisasi yang berkaitan dengan Peraturan Daerah tentang pengelolaan sampah, $62 \%$ dari administrator pemerintah tingkat kelurahan menyatakan pernah melakukannya, sedangkan $38 \%$ sisanya mengaku tidak pernah melaksanakannya.

\section{Upaya Administrator Pemerintahan dalam Mengalokasikan Dana Untuk Pengelolaan Sampah}

Selain melakukan kajian atau penelitian terkait dengan pengelolaan sampah, maka yang tidak kalah penting adalah pengalokasian anggaran yang dilakukan Pemerintah Daerah dalam kaitanya dengan program-program pengelolaan sampah. Karena tanpa anggaran yang memadai berbagai kreatifitas program-program dan langkah-langkah yang direncanakan untuk mengelola sampah tidak akan dapat dilaksanakan dengan optimal.

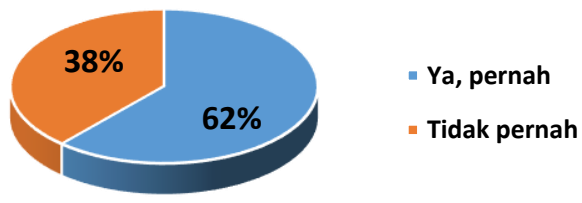

Gambar 19. Kegiatan Sosialisasi PERDA Pengelolaan Sampah oleh Administrator Pemerintahan

Sebanyak 54\% dari administrator pemerintah tingkat kelurahan menyatakan bahwa anggaran/dana yang dialokasikan untuk pengelolaan sampah tidak/belum memadai. Sedangkan yang menyatakan cukup memadai ada sekitar $31 \%$. Serta sisanya sekitar $15 \%$ mengaku tidak tahu tentang hal ini. Hal ini perlu mendapat perhatian serius, sehingga kedepannya ketersediaan anggaran/dana yang memadai bisa dijamin untuk mendapatkan pengelolaan sampah yang lebih optimal lagi.

Sedangkan untuk ketersediaan anggaran yang berasal selain dari APBD (swadaya, dan lain-lain) ada sekitar $8 \%$ yang menyatakan memiliki hal tersebut. Sedangkan sekitar $77 \%$ atau mayoritas dari administrator pemerintah tingkat kelurahan menyatakan tidak ada. Dan sisanya sekitar 15\% mengaku tidak tahu tentang hal tersebut.

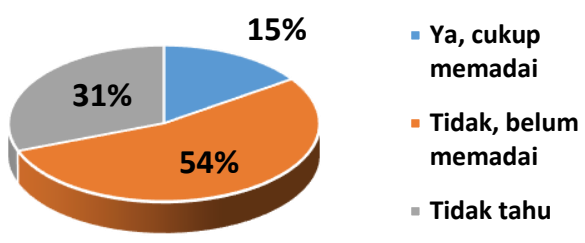

Gambar 20. Kecukupan Anggaran APBD untuk Pengelolaan Sampah Menurut Administrator Pemerintahan

\section{Keberadaan Dukungan Eksternal Terhadap Administrator Pemerin- tahan dalam Kegiatan Pengelolaan Sampah}

Menurut $77 \%$ dari administrator pemerintah tingkat kelurahan telah ada partisipasi masyarakat dalam pengelolaan sampah, walaupun masih belum maksimal. Sedangkan 15\% menyatakan tidak ada partisipasi dari masyarakat, dan sisanya sebanyak $8 \%$ mengaku tidak tahu.

Sedangkan untuk partisipasi dari pemilik usaha/perusahaan, hanya sekitar 8\% dari administrator pemerintah 
tingkat kelurahan yang menyatakan ada walupun belum maksimal, dan lainnya sebanyak $46 \%$ menyatakan tidak ada dan $46 \%$ lainnya mengaku tidak tahu.

Selanjutnya untuk partisipasi dari LSM, hanya sekitar $46 \%$ dari administrator pemerintah tingkat kelurahan yang menyatakan ada walupun belum maksimal, dan sisanya sebanyak 54\% menyatakan tidak ada.

Tidak jauh berbeda dengan partisipasi pemilik usaha/perusahaan, keberadaan partisipasi dari lembaga pendidikan juga hanya diakui oleh $8 \%$ dari administrator tingkat kelurahan. Sedangkan sebagian besarnya itu sebanyak $46 \%$ mengaku tidak tahu, dan $38 \%$ menyatakan ada walaupun belum maksimal. Yang cukup menggembirakan yaitu ada sekitar $8 \%$ dari administrator tingkat kelurahan yang mengakui bahwa ada partisipasi dari kelompok ini di wilayahnya.

Selanjutnya secara mayoritas atau sekitar $69 \%$ dari administrator pemerintah tingkat kelurahan menyatakan perlunya dibangun kemitraan dengan sektor bisnis dalam pengelolaan sampah. Sedangkan yang menyatakan tidak perlu hanya sekitar $23 \%$ dan sisanya sebanyak $8 \%$ menyatakan belum perlu untuk sekarang.

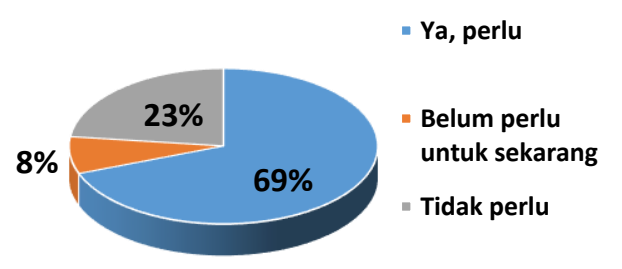

Gambar 21. Perlunya Dibangun

Kemitraan Dengan Sektor Bisnis

Menurut Administrator Pemerintahan

\section{KESIMPULAN}

Berdasarkan hasil dan pembahasan pada bab IV dapat ditarik beberapa kesimpulan, antara lain:
1. Total timbulan sampah perhari di kota sorong sebesar 170.547,75 $\mathrm{kg} /$ hari dari 6 (enam) distrik di Kota Sorong, dengan rata-rata timbulan sampah perhari sebesar 28.424,63 $\mathrm{kg} / \mathrm{hari}$ atau 17.054,78 liter/hari atau $17,05 \mathrm{~m}$ 3/hari yang diasumsikan dari berat jenis sampah nasional dimana sampah $1 \mathrm{~kg}$ sama dengan 0,6 liter.

2. Proses pengelolaan sampah botol air mineral pada dasarnya dikelola oleh pemerintah dan masyarakat. Pengelolaan persampahan yang dikelola oleh pemerintah daerah adalah dengan sistem pengelolaan sampah secara terpadu.Pengelolaan sampah yang dilakukan masyarakat adalah pengelolaan sampah secara individu yaitu dengan cara pembakaran dan ditimbun untuk mengurangi volumenya dan pembuangan akhir berupa penimbunan sisapembakaran serta sampah lainnya yang tidak dapat dibakar.Sistem ini dapat dilakukan diwilayah yang belum dapat dilayani oleh sistem pengelolaan terpadu.

3. Faktor-faktor yang diduga memberikan pengaruh terhadap banyaknya sampah plastik di Kota Sorong antara lain:

a. Tingkat Pengetahuan Masyarakat dan pemilik usaha/perusahaan Tentang Sampah;

b. Sikap Masyarakat dan pemilik usaha/perusahaan Tentang Pengelolaan Sampah;

c. Perilaku Masyarakat dan pemilik usaha/perusahaan dalam Pengelolaan Sampah;

d. Upaya Administrator Pemerintahan Dalam Melakukan Kajian atau Sosialisasi Tentang Pengelolaan Sampah Kepada Masyarakat;

e. Upaya Administrator Pemerintahan dalam Mengalokasikan Dana Untuk Pengelolaan Sampah; 
f. Keberadaan Dukungan Eksternal Terhadap Administrator Pemerintahan dalam Kegiatan Pengelolaan Sampah.

4. Jika dibandingkan dengan beberapa daerah lainnya pengetahuan masyarakat Kota Sorong sudah cukup baik, bahkan lebih baik dari beberapa kota besar lainnya di Indonesia. Namun yang perlu dibenahi adalah partisipasi dari masyarakat yang tercermin dari perilakunya, dimana masih terdapat sebagian masyarakat yang memiliki perilaku tidak baik dalam pengelolaan sampah, seperti membuang sampah di sungai, pantai, dll.

\section{DAFTAR PUSTAKA}

BPS Kota Sorong. 2016. Kota Sorong Dalam Angka 2016. Kota Sorong.

Essuman, Nasir Kofi. 2017. Knowledge, Attitudes and Practices of Coastal Communities on Waste Management in Ghana. Thesis for Novia University of Applied Sciences - degree. Raseborg/ Raasepori, 2017.

Marojahan, Ricky. 2015. "Hubungan Pengetahuan Masyarakat Tentang Sampah Dengan Perilaku Mengelola Sampah Rumah Tangga di RT 02 dan RT 03 Kampung Garapan Desa Tanjung Pasir Kecamatan Teluk Naga Kabupaten Tangerang." Forum Ilmiah Vol: 12 Nomor 1, Januari 2015.

Mulasari, Surahma Asti. 2012. "Hubungan Tingkat Pengetahuan dan Sikap Terhadap Perilaku Masyarakat dalam Mengolah Sampah di Dusun Padukuhan Desa Sidokarto Kecamatan Godean Kabupaten Sleman Yogya- karta." Kes Mas Vol: 6 No. 3, September 2012: 144 - 211.

Mungure, J.M., 2008, Governance and community participation in Municipal Solid Waste management, case of Arusha and Dar es Salaam Tanzania

Murtadho Djuli dan Sa'is Gumbira E., 1988. Penanganan dan Pemanfaatan Limbah Padat. Mediyatama Sarana Perkasa. Jakarta.

PP Nomor 81 Tahun 2012 Tentang Pengelolaan Sampah Rumah Tangga dan Sampah Sejenis Sampah Rumah Tangga.

Perda Nomor 14 Tahun 2012 Tentang Retribusi Sampah.

Perda Nomor 15 Tahun 2013 Tentang Pengelolaan Persampahan.

Walpole Ronald E, Raymond H Myers. 1995. "Ilmu Peluang Dan Statistika untuk Insinyur dan Ilmuwan", edisi ke-4, Penerbit ITB, Bandung. 